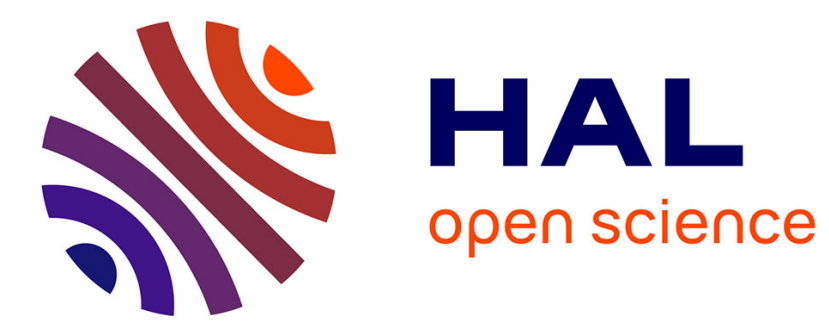

\title{
Storm surges and coastal flooding: status and challenges
}

Xavier Bertin

\section{To cite this version:}

Xavier Bertin. Storm surges and coastal flooding: status and challenges. La Houille Blanche - Revue internationale de l'eau, 2016, pp.64 - 70. 10.1051/lhb/2016020 . hal-01453445

\section{HAL Id: hal-01453445 \\ https://hal.science/hal-01453445}

Submitted on 2 Feb 2017

HAL is a multi-disciplinary open access archive for the deposit and dissemination of scientific research documents, whether they are published or not. The documents may come from teaching and research institutions in France or abroad, or from public or private research centers.
L'archive ouverte pluridisciplinaire HAL, est destinée au dépôt et à la diffusion de documents scientifiques de niveau recherche, publiés ou non, émanant des établissements d'enseignement et de recherche français ou étrangers, des laboratoires publics ou privés. 


\title{
Storm surges and coastal flooding: status and challenges
}

\author{
Xavier BERTIN
}

UMR 7266 LIENSs, CNRS-Université de La Rochelle, FRANCE, xbertin@univ-lr.fr

\begin{abstract}
Storm surges and associated coastal flooding are among the most damaging natural disasters, as it was illustrated recently in the Gulf of Mexico, the Bay of Bengal or the Philippines. Storm surges correspond to sea-level anomalies, driven by atmospheric pressure, wind and short waves. In shallow waters, the wind contribution is usually dominant upon the other forcing, which causes coastal areas bordered by extensive shelves and located along the track of major storms to be exposed to very large surges. For a given wind speed, the surface stress can also be amplified by seastates, for instance in the presence of young and steep waves. The Coriolis effect associated with the Earth rotation is also an important process because it deviates wind-driven flows to the right (to the left) in the Northern (Southern) hemisphere, which can result to an Ekman setup along the coast located to the right-side (resp. left-side) of the storm track. Finally, wave dissipation in surf zones induces gradients of radiation stress, which drives a wave-setup easily reaching several tens of $\mathrm{cm}$ and therefore contribution to the whole storm surge. Coastal flooding usually happens when a large storm surge peak at the same time of a high tide, although the importance of this concomitance depends and surge to tidal range ratio. Coastal flooding can occur through dike and barriers overflowing, breaching, or a combination of both mechanisms. Along the coastline exposed to big waves, wave overtopping can also induce significant flooding and damage sea-front. However, resolving short-wave phases to account for this phenomenon implies a very fine resolution, which poses a serious challenge in terms of computational resources.
\end{abstract}

\section{KEY WORDS}

Storm surge, surface stress, continental shelf, short waves, coastal flooding.

$$
\text { Surcotes et submersions marines : état de l'art et défis }
$$

\section{RESUME}

Les surcotes et les submersions marines associées sont parmi les catastrophes naturelles les plus destructrices, comme cela a été illustré récemment dans le Golfe du Mexique, le Golfe du Bengale ou les Philippines. Les surcotes correspondent à des anomalies du niveau de la mer, entraînées par la pression atmosphérique, le vent et des vagues. En eau peu profonde, la contribution de vent est en général dominante sur les autres mécanismes, ce qui explique que les zones côtières bordées par de larges plateaux continentaux et situées sur le trajet de tempêtes majeures peuvent être exposées à de très fortes surcotes. Pour une vitesse du vent donnée, la contrainte de surface peut aussi être amplifiée par l'état de mer, par exemple en présence de vagues jeunes et cambrées. L'effet de Coriolis associé à la rotation de la terre est aussi un processus important parce qu'il dévie les masses d'eau transportées par le vent vers la droite (la gauche) dans l'hémisphère nord (sud), ce qui peut entraîner un transport d'Ekman et une surcote plus importante le long de la côte située à droite (resp. à gauche) de la trajectoire de la tempête. Enfin, la dissipation des vagues dans les zones de déferlement induit des gradients de tension de radiation, ce qui génère une surélévation du plan d'eau le long $d u$ rivage pouvant atteindre facilement plusieurs dizaines de cm et donc contribuer aux surcotes significativement. Les submersions marines se produisent d'habitude quand une grande tempête atteint un niveau maximal en même temps qu'une marée haute, bien que l'importance de cette concomitance dépende du ratio entre la surcote et le coefficient de marée. Les submersions marines peuvent résulter d'un débordement au dessus des digues et des barrières, de brèches, ou d'une combinaison des deux mécanismes. Le long du littoral exposé à de grandes vagues, le franchissement par paquet de mer peut aussi induire une inondation significative et endommager le bord de mer. Cependant, la prise en compte de ce phénomène implique des résolutions spatio-temporelles très fines, ce qui constitue un défi sérieux en termes de ressource informatique.

\section{MOTS CLEFS}

Surcotes, contrainte de surface, plateau continental, vagues, submersions marines

\section{INTRODUCTION}

Tropical cyclones and extra-tropical storms hitting coastal zones are among the most destructive natural disasters. Generally, the main part of the material damages and human losses is induced by coastal flooding rather than direct wind effects. Coastal flooding predominantly occurs in low-lying zones under the 
concomitance of a large storm surge and a high spring tide, although the importance of this concomitance also depends on the ratio between the storm surge and the local tidal range. Storm surges correspond to nonastronomic variations in the ocean free-surface driven by meteo-oceanic forcing. Storm surges larger than 9 $\mathrm{m}$ were already reported in the Gulf of Mexico during hurricane Katrina in 2005 (Blake, 2007) and in the Bay of Bengal, which are long known to be regions in the world the most exposed to major storm surges and coastal flooding. Recent examples such as storm Sandy in the New York area (2012) and typhoon Haiyan in the Philippines (2013), which drove storm surge in the range 3-6 m, illustrate that other regions in the world are exposed to large storm surges and coastal flooding. In Europe, the most dramatic catastrophe in the modern history occurred in the Southern part of the North Sea in January 1953, when a big storm produced a surge locally larger than $3 \mathrm{~m}$ in phase with spring tides (Wolf and Flather, 2005), which caused the flooding of low-lying coastal zones of The Netherlands, Belgium and South-East UK and cost more than 2000 lives. Besides being located along the track of major storms, these vulnerable regions systematically exhibit lowlying coastal zones bordered by shallow waters and/or extensive continental shelves (figure 1B and 1C). A detailed examination of the bathymetry surrounding the vulnerable coastal zones listed above reveals that continental shelves range from 150 to $700 \mathrm{~km}$ and that depth lower than $50 \mathrm{~m}$ extend $50 \mathrm{~km}$ around the shoreline. The relationship between the height of the storm surge and the bathymetry is explained through the governing shallow water equations, where the wind effect is inversely proportional to the water depth. As a consequence, in shallow waters, the wind effect is often dominant over the well known "inverse barometer effect' (Doodson, 1924) caused by atmospheric pressure gradients (Rego and Li, 2010). In the nearshore, wave dissipation induces gradients of radiation stress (Longuet Higgins and Stewart, 1964) that drive a setup easily reaching several tens of centimeters during storms and therefore contribute to the storm surge. In volcanic islands where continental shelves are almost absent, the wind contribution in the storm surge is often very weak, which can cause the contribution of wave setup be dominant over the other contributions (e.g. Kennedy et al., 2011).
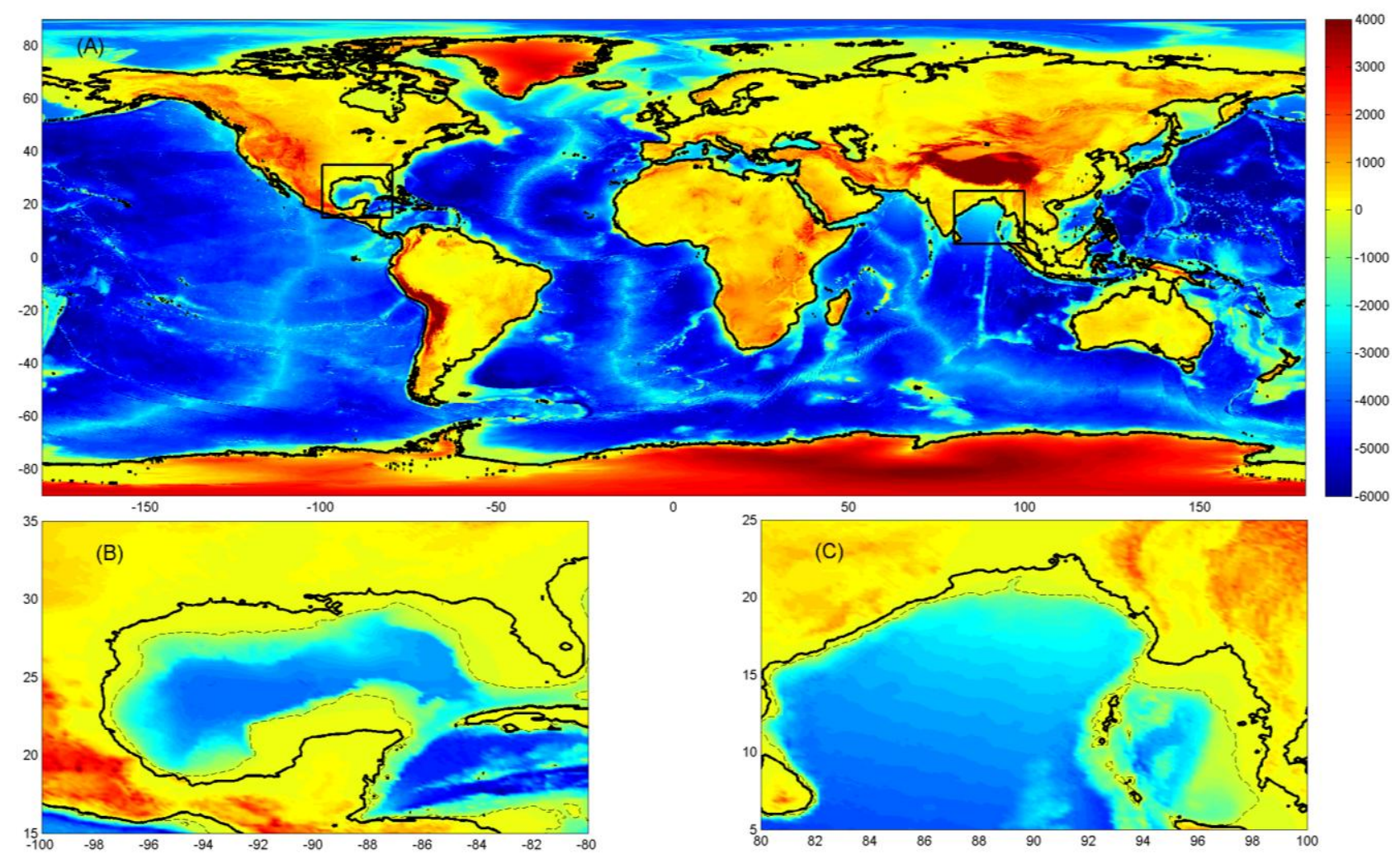

Figure 1. (A) Bathymetric/topographic map of the world and zoom-in on the Golfe of Mexico (B) and the Bay of Bengal (C), being the region of the world where the largest surges were ever reported. The -200 isobath (dotted line) shows that the continental shelf in these regions locally exceeds $200 \mathrm{~km}$.

This study presents firstly a review on the physical processes controlling storm surges and how they are represented in numerical modeling systems. This review is based on several examples taken from the abundant literature published after the catastrophes that occurred over the last decade in the USA and in 
Europe. The different mechanisms leading to coastal flooding are then explained and some successful modeling approaches are presented.

\section{THE MECHANISMS CONTROLLING STORM SURGE}

As for the coastal circulation in general, the generation and propagation of storm surges is usually well described by the depth-integrated shallow water equations (Saint-Venant equations). This simplification is only more questionable for estuaries when stratification occurs or in larger water depths where the fast moving upper layer of the ocean is poorly represented by depth-integrated velocities. Including the source terms associated with storm surges, the governing equations read:

$$
\begin{aligned}
& \frac{\partial \zeta}{\partial t}+\frac{\partial(\zeta+h) u}{\partial x}+\frac{\partial(\zeta+h) v}{\partial y}=0 \\
& \frac{D u}{D t}=f v-g \frac{\partial \zeta}{\partial x}-\frac{1}{\rho_{w}} \frac{\partial P_{a t m}}{\partial x}+\frac{\tau_{s x}-\tau_{b x}}{\rho_{w} \cdot(\zeta+h)}-\frac{1}{\rho_{w} \cdot(\zeta+h)}\left(\frac{\partial S_{x x}}{\partial x}+\frac{\partial S_{x y}}{\partial y}\right) \\
& \frac{D v}{D t}=-f u-g \frac{\partial \zeta}{\partial y}-\frac{1}{\rho_{w}} \frac{\partial P_{a t m}}{\partial y}+\frac{\tau_{s y}-\tau_{b y}}{\rho_{w} \cdot(\zeta+h)}-\frac{1}{\rho_{w} \cdot(\zeta+h)}\left(\frac{\partial S_{y y}}{\partial x}+\frac{\partial S_{x y}}{\partial x}\right)
\end{aligned}
$$

where $\zeta$ is the free surface elevation, $\mathrm{u}$ and $\mathrm{v}$ are the horizontal component of the depth-integrated velocity, $\mathrm{h}$ is the bathymetry, $\rho_{\mathrm{w}}$ is water density, $\mathrm{g}$ is the acceleration of the gravity, $\mathrm{f}$ is the Coriolis parameter, $\mathrm{P}_{\mathrm{A}}$ is the sea-level atmospheric pressure, $\tau_{\mathrm{b}}$ and $\tau_{\mathrm{s}}$ are the bottom and surface stress, respectively. Finally, $\mathrm{S}_{\mathrm{xx}}, \mathrm{S}_{\mathrm{xy}}$ and $S_{y y}$ are the wave radiation stresses. Considering an axis perpendicular to a uniform shoreline and under steady state (which implies that the cross-shore component of the depth-integrated velocity $u$ is nil), the source terms responsible for the storm surge are balanced by the barotropic pressure gradient:

$$
g \cdot \frac{\partial \zeta}{\partial x}=-\frac{1}{\rho_{w}} \frac{\partial P_{a t m}}{\partial x}+\frac{\tau_{s x}}{\rho_{w} \cdot(\zeta+h)}-\frac{1}{\rho_{w} \cdot(\zeta+h)}\left(\frac{\partial S_{x x}}{\partial x}\right)
$$

The three terms on terms on the right hand side of Eq. (4) correspond the atmospheric pressure gradient, the wind-induced surface stress and the shore normal component of wave forces. These are the main driving processes for storm surges, which will be detailed in the following subsections.

\subsection{Atmospheric pressure}

The effect of atmospheric pressure gradients on sea-level variations was recognized very early and referred to as "inverse barometric effect (e.g. Doodson, 1924). The associated empirical rule states that a variation of $1 \mathrm{mBar}$ with respect to the mean sea-level atmospheric pressure $(1013 \mathrm{mBar})$ causes a $1 \mathrm{~cm}$ variation in sea-level. Although very simple, this empirical rule holds as long as changes in atmospheric pressure are slow-enough so that the dynamics associated with sea-level adjustment is negligible. For extreme tropical hurricanes where the minimum sea-level pressure can reach $900 \mathrm{mBar}$ or less, the contribution of this effect in the storm surge can thus exceed $1.0 \mathrm{~m}$. Otherwise, the term corresponding to the atmospheric pressure gradient being independent from the water depth, its contribution to the total storm surge is often dominant in deep water or at volcanic island where the continental shelf is restricted or absent.

\subsection{Surface stress}

\subsubsection{Bulk formula}

For a long time, it has been common practice to compute the wind surface stress $\tau_{\mathrm{s}}$ based on bulk formula (Eq.1): 
$\tau_{s}=\rho_{a} \cdot C_{d} \cdot U_{10}^{2}$

where $\rho_{\mathrm{a}}$ is the air density, $\mathrm{U}_{10}$ the $10 \mathrm{~m}$ wind speed and $\mathrm{C}_{\mathrm{d}}$ is a drag coefficient corresponding to the sea roughness that increases linearly with the wind speed for low to moderate winds (e.g. Pond and Pickard, 1998). However, although the simplicity of such formulae could make it attractive to implement in storm surge model, it has two main shortcomings. First, several recent studies relying on field and laboratory measurements suggested that under extreme winds, the sea roughness could reach a maximum or even decrease (figure 2) due to wave-induced streaks of foam and sprays for winds larger than $35-40 \mathrm{~m} / \mathrm{s}$ (Powell et al., 2003; Takagaki et al., 2012). Second, the scatter shown on figure 2 is partly explained by the fact that the sea roughness doesn't only depend on the wind speed but can also be impacted by the sea-state. This phenomenon will be further developed in the next sub-section.

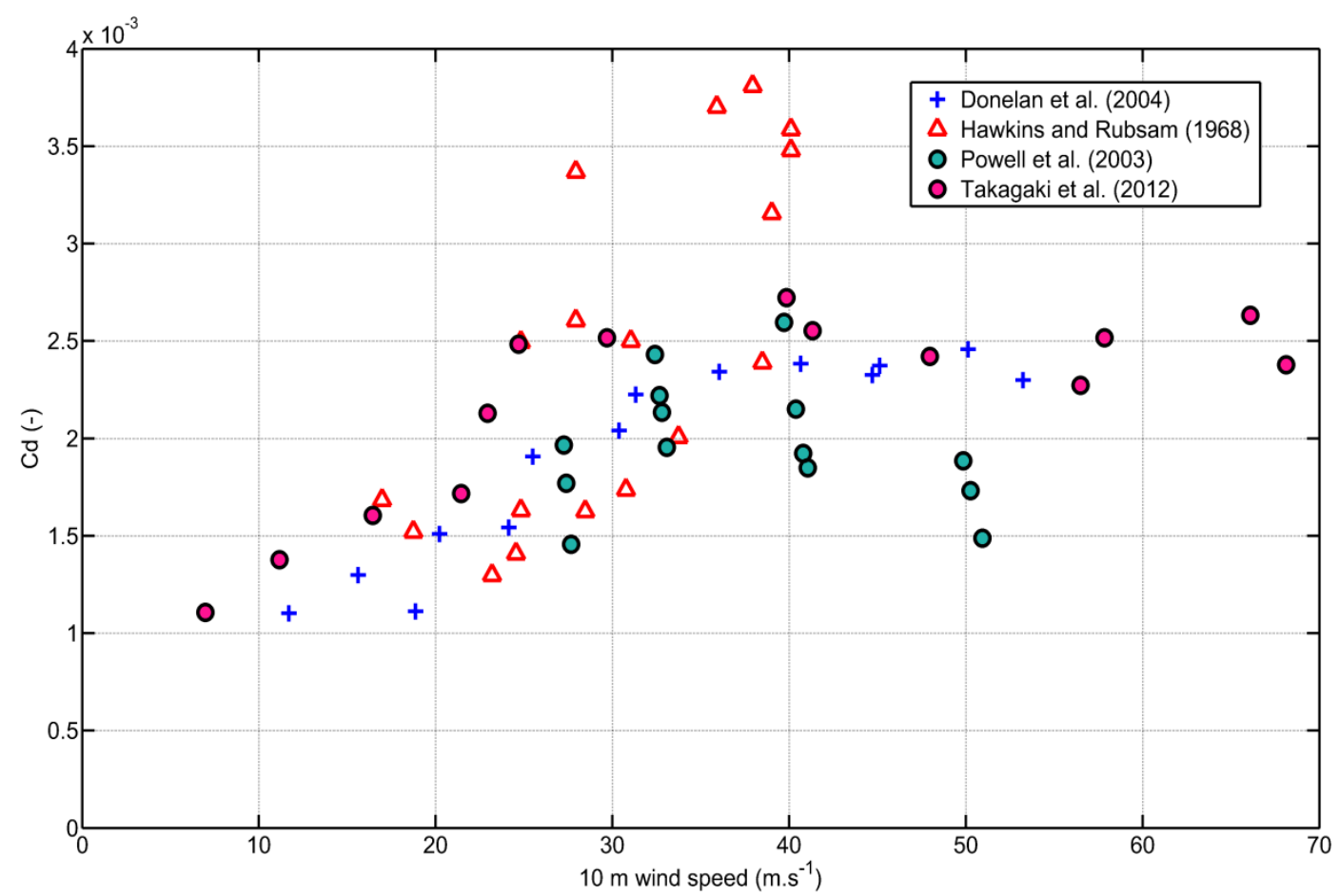

Figure2. Sea-surface drag coefficient as a function of wind speed (modified after Takagaki et al., 2012)

\subsubsection{Wave dependence}

Based on the pioneer work of Charnock (1955), Stewart (1974) proposed that the sea roughness should also depends on the wave age for a given wind speed, which can be defined as the ratio between the wave phase speed and the friction velocity. The dependence of the surface stress to the sea state was then corroborated in many studies (Mastenbroek et al., 1993; Moon, 2005; Brown and Wolf, 2009; Bertin et al., 2012; Olabarrieta et al., 2012). 

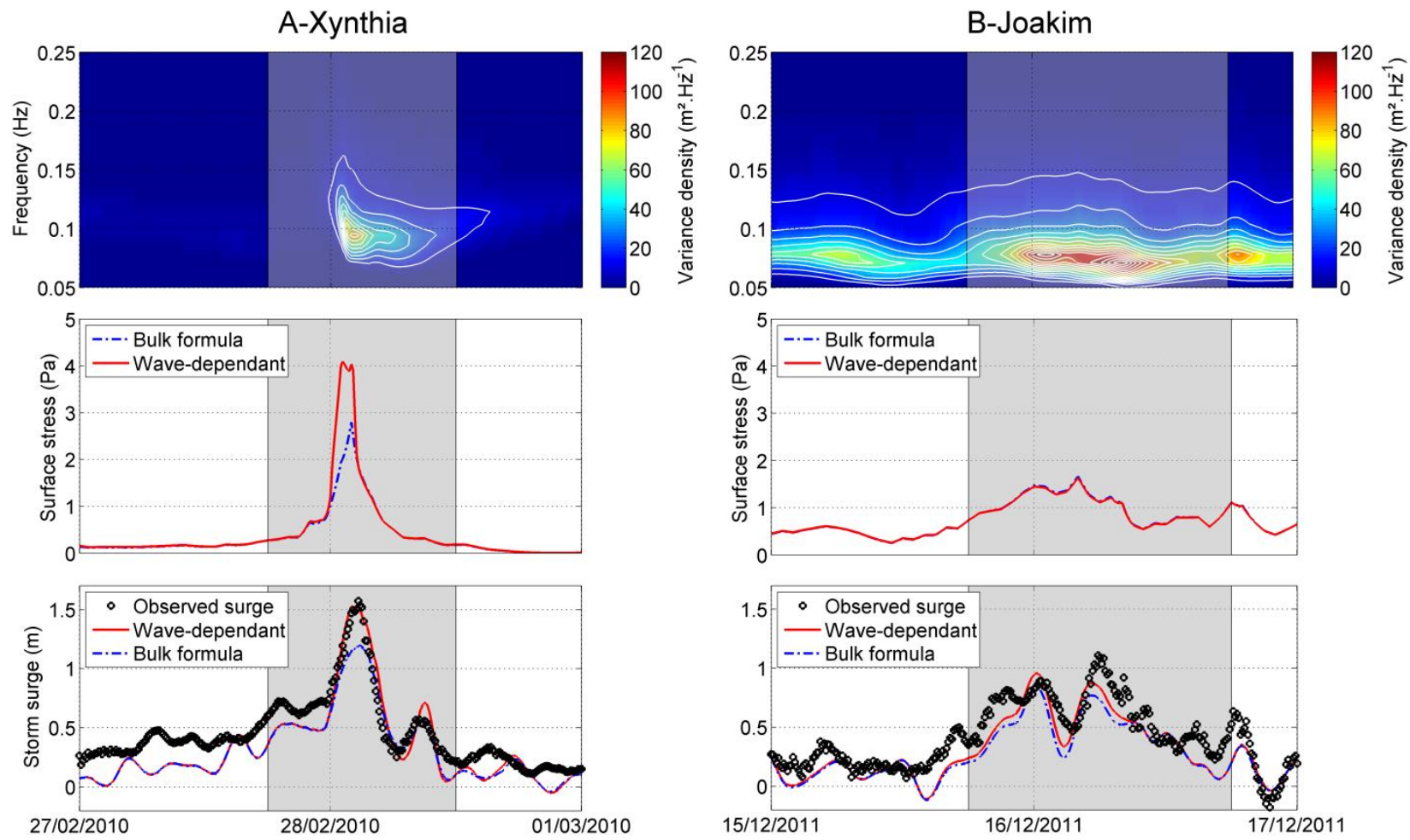

Figure 3. Time-series of energy density $\left(\mathrm{m}^{2} \cdot \mathrm{Hz}^{-1}\right.$, upper panel), surface stress (Pa, middle panel) and storm surge at La Rochelle, for Xynthia (left) and Joakim (right) (modified after Bertin et al., 2015).

The importance of this phenomenon was recently demonstrated by Bertin et al. (2015), who performed a comparison between two storms that recently affected the central part of the Bay of Biscay. Despite displaying comparable wind fields in the study area, these two storms induced very different storm surges and sea states. The former storm, Xynthia $\left(27-28^{\text {th }}\right.$ of February 2010), was characterized by large (up to $7 \mathrm{~m}$ significant wave height $\mathrm{Hs}$ ) and short-period waves and induced an exceptional storm surge for the study area, locally larger than $1.6 \mathrm{~m}$. The second storm, Joachim $\left(15-16^{\text {th }}\right.$ of December 2011), was characterized by very large (up to $\mathrm{Hs}>10 \mathrm{~m}$ ) and long-period waves but only induced a storm surge almost two times lower. The analysis of modeling results revealed that the very large differences in surges induced by these two storms originated from major differences in sea states (figure 3).

Time-series of energy spectra (figure 3-a) showed that, for Xynthia, a lot of energy was found in the range $0.10-0.15 \mathrm{~Hz}$, with levels reaching $70 \mathrm{~m}^{2} . \mathrm{Hz}-1$. This spectral repartition strongly differs for Joachim, where maximum energy in this frequency band reaches $30 \mathrm{~m}^{2} . \mathrm{Hz}-1$ although the total energy was much larger. Such conditions during Xynthia are representative of a very young sea state, characterized by steep waves, which enhanced the surface stress up to a factor two (figure 3-B). These results suggest that the bulk formula may only perform for average sea-states, otherwise a wave-dependent formula should be employed to compute the surface stress.

\subsubsection{Ekman Transport}

Due to the Earth Rotation, the wind-driven flow is deviated to the right (respectively to the left) in the Northern Hemisphere (in the Southern Hemisphere). At the surface, this deviation is theoretically of $45^{\circ}$ under steady state although several studies documented smaller values in the range $20-30^{\circ}$ (e.g. Holmedal and Myrhaug, 2013). When going down in the water column, the current velocity decreases until to the socalled Ekman layer is reached while the current direction also shifts to the right (resp. to the left). Under steady state and in deep water, the net water transport is oriented at $90^{\circ}$ to the right of the wind direction (resp. to the left), although this value tends to decrease in shallow water due to the increase in bottom stress (Rego and Li, 2010). When a storm approaches the coast, the alongshore component of wind stress drives an "Ekman setup" (Kennedy et al., 2011) at the coast located to the right-side of the wind (to left-side in the Southern Hemisphere). As an important consequence, the coastal region located to the right-side of the storm 
track usually suffers larger storm surge and damages than the coastal region located to the left side. This phenomenon was impressively demonstrated by Kennedy et al. (2011), who reported a large water level anomaly along the coasts of Louisiana and Texas (USA) 12-24 h before the landfall of Hurricane Ike (2008) and attributed the origin of these forerunners anomalies to such an Ekman setup (figure 4). This interesting case study was hindcast with the storm surge modelling system described in Bertin et al. (2015), forced with wind fields and sea-level pressure originating from the CFSR reanalysis (Saha et al., 2010). An unstructured grid was implemented over the Gulf of Mexico (figure 4-a) with a spatial resolution ranging from $20 \mathrm{~km}$ in the deep ocean to $1 \mathrm{~km}$ along the coastline.

In order to quantify the impotance of the Ekman transport, the model was run without the Coriolis term and subsequent Ekman forcing. In the Coriolis-free simulation, the forerunner surge no longer develops and the water level is up to two meters lower than measured before landfall. The surge peak is also underestimated by almost $1.0 \mathrm{~m}$. These results demonstrate that the storm track, which controls wind direction, should be considered very important.
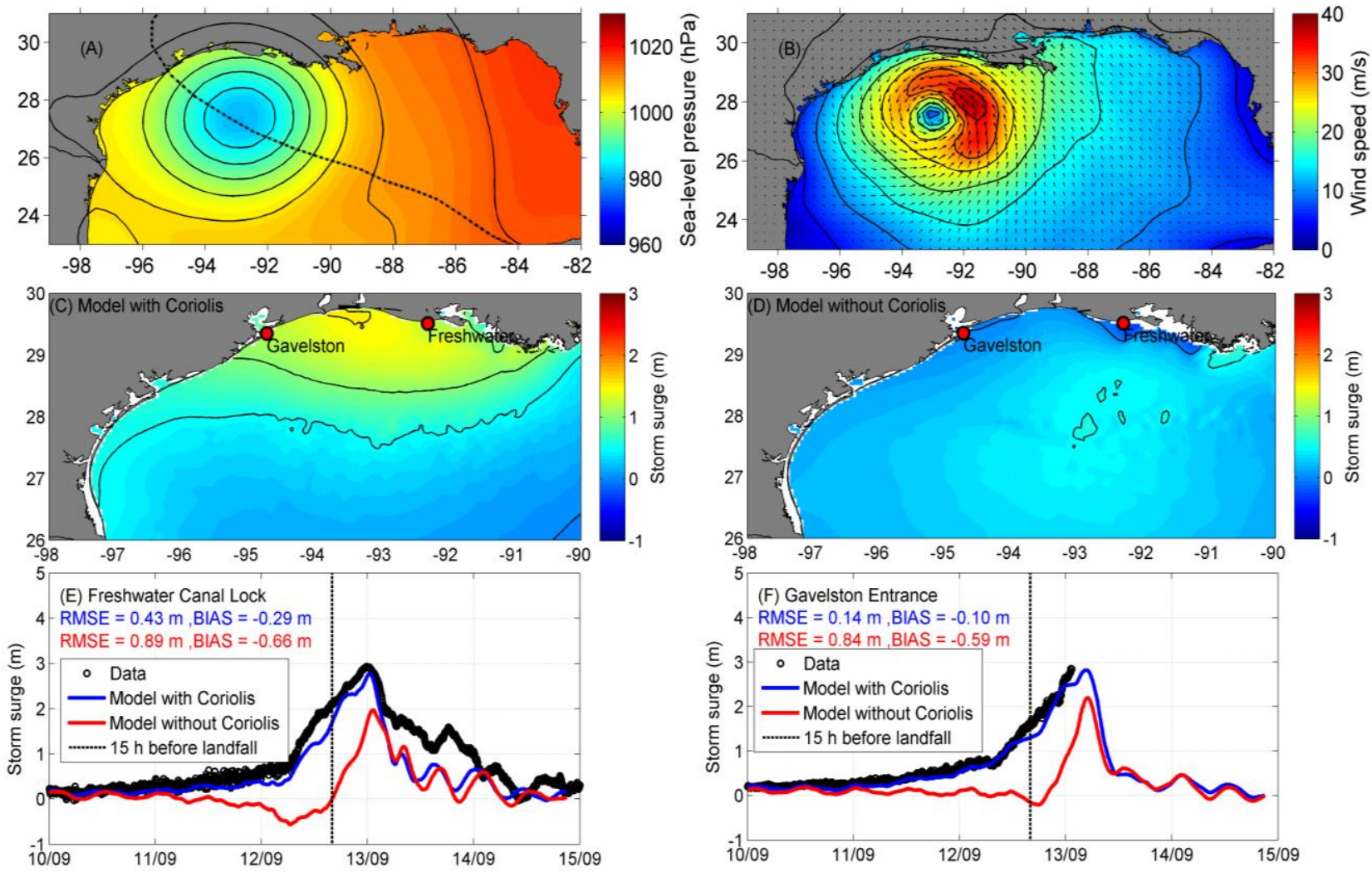

Figure 4 Sea-level pressure during Ike (A), $10 \mathrm{~m}$ wind speed (B), modeled storm surge with (C) and without (D) Coriolis term, observed vs modeled storm surge at Freshwater (E) and Gavelston (F), showing that the storm surge is much better reproduced when Coriolis is taken into account.

\subsection{Short waves breaking}

In the nearshore, wave dissipation related to depth-limited breaking induces radiation stress gradients which drive currents as well as a setup along the coast. Under big waves, this setup can easily reach several tens of $\mathrm{cm}$ and therefore contribute to the storm surge significantly. This contribution can even be dominant upon other forcing at volcanic islands and coastal zones bordered by narrow continental shelf (e.g. Kennedy et al., 2012). Recent studies also showed that wave setup can even propagate outside surf zones and thereby contribute to the storm surge in areas sheltered from wave breaking such as coastal lagoons (e.g. Bertin et al., 2009; Dodet et al. 2013), estuaries (Bertin et al., 2015) and tropical lagoons bordered by coral reefs (Aucan et al. 2012). Bertin et al. (2015) investigated numerically the contribution of wave setup in the central part of the Bay of Biscay during storm Joakim (December 2011) characterized by offshore significant wave height larger than $10 \mathrm{~m}$ and showed that wave setup of the order of $0.2 \mathrm{~m}$ developed outside surf zones at regional scale (figure 5). 


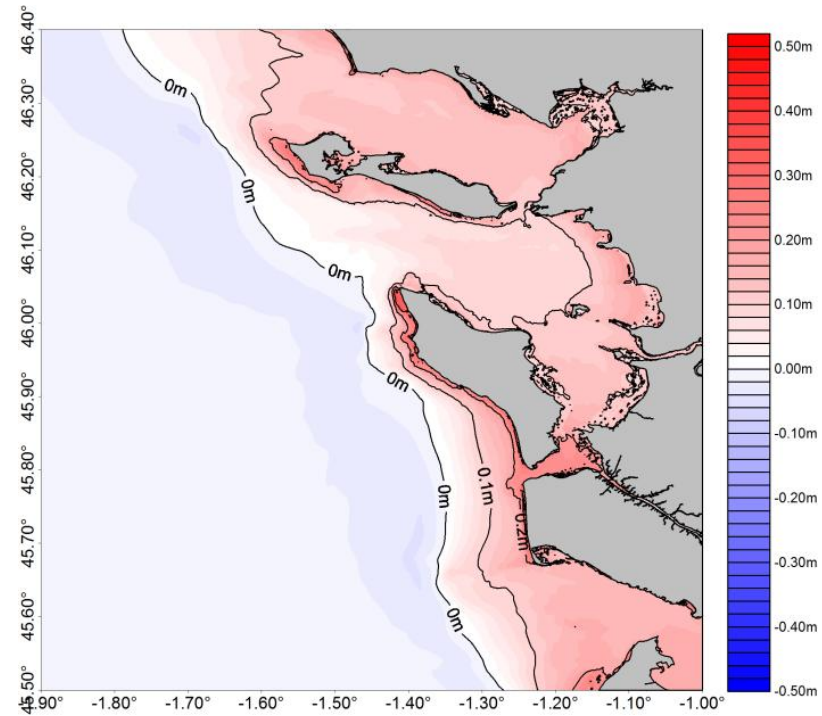

Figure 5. Contribution of wave setup in the storm surge associated with storm Joakim (december 2011) in the central part of the Bay of Biscay. Modified from Bertin et al. (2015).

In addition to this phase-averaged wave-induced surge, wave breaking along the coast induce wave runup that can reach several meters above the aforementioned still water level. However, the proper representation of this phenomenon is not possible with the system of equations presented above while representing short-wave phases requires a very fine spatial resolution (i.e. $<1 \mathrm{~m}$ ). Successful approaches where developed for $1 \mathrm{D}$ cross-shore profiles of $2 \mathrm{D}$ very small domains, either using Boussinesq models (e.g. Kennedy et al., 2012) of 2DH models including a correction to account for non-hydrostatic pressure term (e.g. Roelvink, 2009). Finally, wave groupiness can induce large infragravity waves, which can modulate the still water level by several tens of $\mathrm{cm}$. This phenomenon can induce large damages along seafronts, although its representation in numerical models was only achieved recently (e.g. Roelvink, 2009) and further developments will be required to account for it a regional scales.

\section{STORM-INDUCED COASTAL FLOODING}

Once oceanic water levels are correctly reproduced along the coastline, the simulation of associated flooding would theoretically be easily achievable. However, the proper simulation of storm-induced flooding constitutes a multi-scale and very challenging problem for several reasons. First, large geographical extend are required to adequately reproduce wave development and atmospheric pressure effect while very high resolution (i.e. $<10 \mathrm{~m}$ ) should be employed locally to represent correctly dikes and natural barriers in the computational grid. Second, efficient and very stable numerical methods should be employed to deal with large variability of Courant numbers, strong spatial gradients along the dikes and barriers and wetting and drying. Finally, to date, dike breaching under wave breaking has never been integrated within a storm surge/flooding modelling system. These challenges probably explain why successful simulations of storminduced flooding remain scarce in the literature. In the following subsections, we will provide examples of successful hindcast of coastal flooding associated overflowing, barrier breaching and wave overtopping.

\subsection{Overflowing over dikes and barriers}

Bertin et al. (2014) performed a fully coupled high-resolution hindcast of the coastal flooding associated with Xynthia, which severely hit the central part of the Bay of Biscay in February 2010. These authors implemented a numerical modeling system that couples the circulation model SELFE (Zhang and Baptista, 2008) and the wind wave model WWMII (Roland et al., 2012). This hindcast uses an unstructured grid covering the whole NE Atlantic Ocean, with a spatial resolution ranging from more than $10,000 \mathrm{~m}$ offshore to locally less than $5 \mathrm{~m}$ along the dikes in the study area. Such a spatial discretization results in a 1,700,000 triangular element grid and the problem of the very large associated computational cost is solved using the parallelized version of the code over $144 \mathrm{CPU}$. 

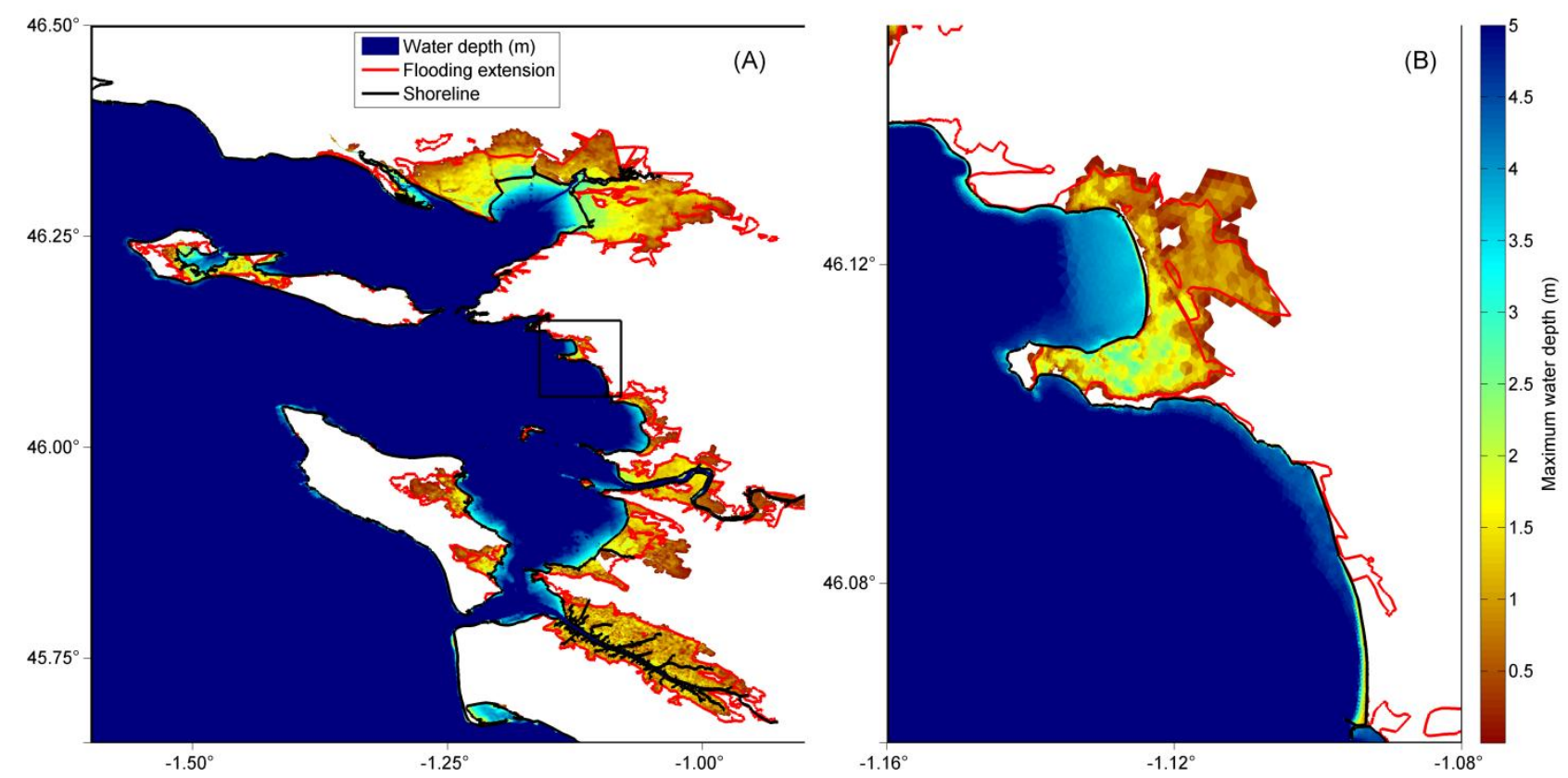

Figure 6. Maximum water levels computed during Xynthia (colorscale), showing that the model reasonnably reproduces the observed extension of the flooding (red line), with the notable exception of several small areas located along the shoreline (modified from bertin et al., 2014).

These modeling results are shown on figure 6 , which reveals firstly that maximum water depth in flooded areas range from about $1 \mathrm{~m}$ over a large part of the study area, to locally more than $3 \mathrm{~m}$ (figure 6a). The comparison with observations reveals that, at regional scale, the model is able to reproduce the extent of the flooding quite reasonably (figure 6-a). The agreement is particularly good in large marshes where the inundation exceeds several tens of $\mathrm{km}^{2}$ (figure 6-a). In more details, the model fails to reproduce the flooding of small areas (i.e. less than $1 \mathrm{~km}^{2}$ ) located along the shoreline (figure 6-b). This problem was explained by the fact that the phase-averaged approach used in this study doesn't allow for the representation of wave runup and infragravity, while model results suggest that waves of the order of $3 \mathrm{~m}$ were breaking in front of these areas during Xynthia. The representation of these phenomenon constitutes a long-term objective, although it poses a serious challenge in terms of computational time.

\subsection{Barrier breaching}

Mc Call et al. (2010) performed a numercial hindcast of the barrier breaching and the flooding of Santa Rosa Island during hurricane Yvan, which severely hit the Golfe of Mexico (figure 1B) in September 2004. These authors used the morphodynamics modeling system X-Beach (Roelvink et al., 2009) to simulate the coastal circulation, the wave propagation and the resulting sediment transport and bottom changes. Comparing to other process-based modeling system, X-Beach offers the possibility to account for infra-gravity waves and sediment avalanching and was designed to simulate the erosion of dunes during storms. Starting from a LIDAR-derived high resolution topography (figure 7A), their model is able to reproduce the flooding and the breaching of Santa Rosa barrier island (figure 7B). The comparison with a LIDAR survey carried out after storm IVAN (not shown) revealed that their modeling system has important skills in predicting morphologigal changes, including the development of overwash fans in the backbarrier lagoons. 

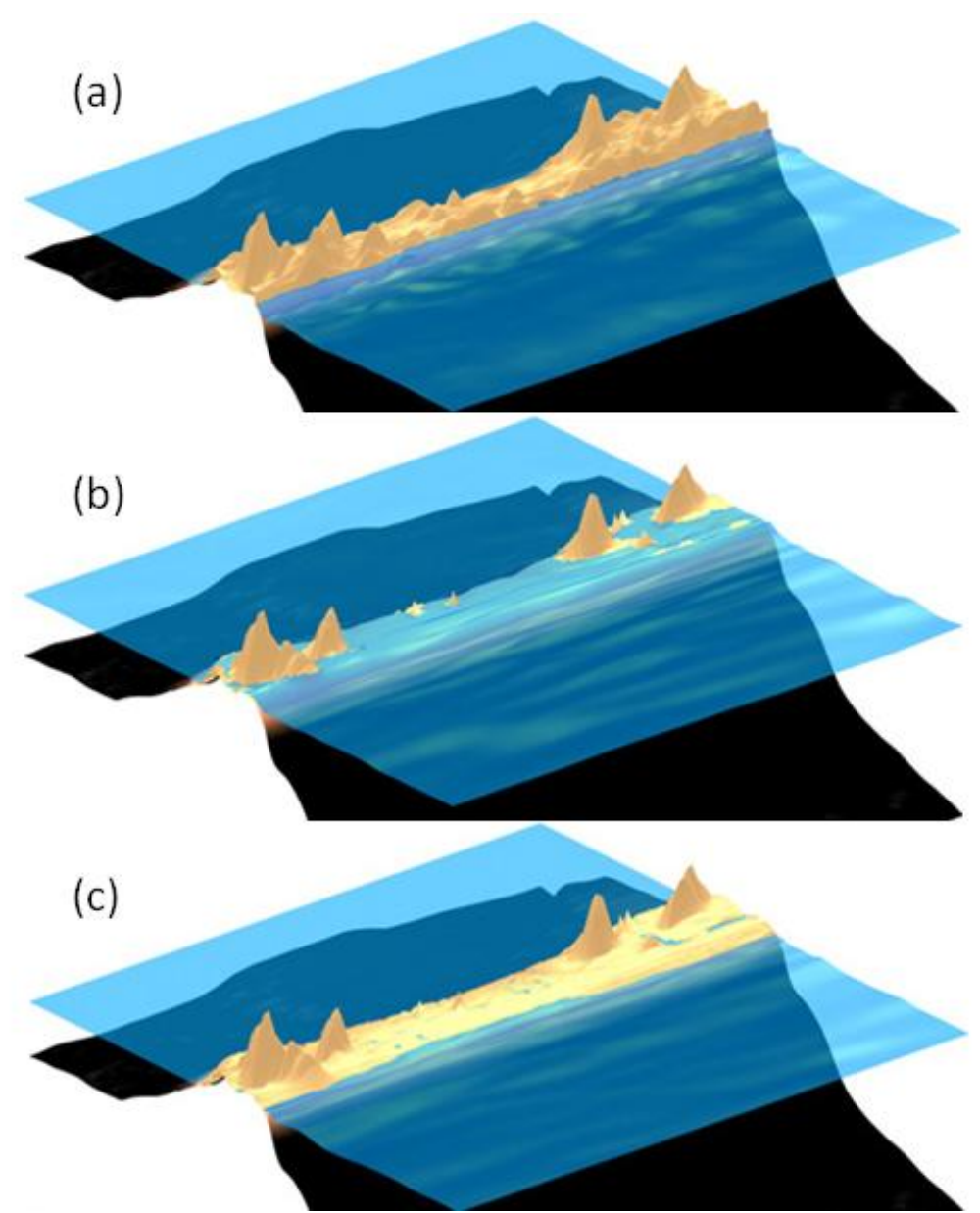

Figure 7. Snapshot of the free-surface elevation and barrier topography at Santa Rosa Island simulated with X-Beach during hurricane Ivan (adapted from McCall et al., 2010).

\subsection{Wave overtopping}

When the still water level is below the barrier or dike crest but the waves are sufficiently large, flooding due to wave overtopping can be significant. However, accounting for this process implies resolving the short-wave phase, which requires very fine space and time discretizations and results in very large computational times. To overcome these problems, several engineering formulae have been proposed, such as the EurOtop formula (Pullen et al., 2007). Alternatively, numerical models solving the Boussinesq equations were already applied with success, although on 1D cross-shore profiles or at very small coastal domains (Lynett et al., 2010; Kennedy et al., 2012). The recent development of coastal models solving the shallow water equations with a correction to account for the non-hydrostatic pressure term (e.g. Zijlema et al., 2011) appears as a very promising perspective to account for wave overtopping at larger spatial scales, although still remaining much more time consuming than phase averaged approaches.

\section{CONCLUSIONS AND FUTURE CHALLENGES}

This study reminded firstly that the regions of the world the most vulnerable to storm-induced flooding were low-lying zones, located along the track of major storms and hurricanes and bordered by large continental shelves and shallow waters. Considering the governing shallow water equations, this last point was explained by the fact that the wind effect is inversely proportional to the water depth. It was also shown that the sea-state can impact the wind effect and that, in the Northern hemisphere, the Coriolis effect caused the coastline located to right of the storm track to suffer much larger surges and flooding (resp. to the left in the Southern hemisphere). Finally, in the nearshore, wave dissipation drives a wave setup along the coastline, which can even propagate outside the surf zone in surrounding estuaries and lagoons.

The second part of this study provided examples of coastal flooding induced by three distinct processes: overflowing, barrier breaching and wave overtopping. Recent studies suggested that wave runup and infragravity waves could now be realistically be represented in operational numerical models, although accounting for these phenomenons at regional scales poses a serious computational challenge. On the other 
hand, the breaching of concrete-made dikes under wave breaking appears as a more challenging process to represent in operational modeling systems.

\section{ACKNOWLEDGEMENTS}

This study is a contribution of the European FP7 project Risc-Kit (Grant Agreement $n^{\circ}$ 603458) and also benefited from the project "Submersion" carried out at UMR LIENSs from 2011 to 2013. This project involved $\mathrm{Kai} \mathrm{Li}$, Jean-François Breilh and Eric Chaumillon and was funded by the General Council of Charente Maritime and FEDER. During this period, several colleagues visited UMR LIENSs during this period: Nicolas Bruneau, André Fortunato and Aron Roland and provided a usefull source of inspiration.

\section{REFERENCES AND CITATIONS}

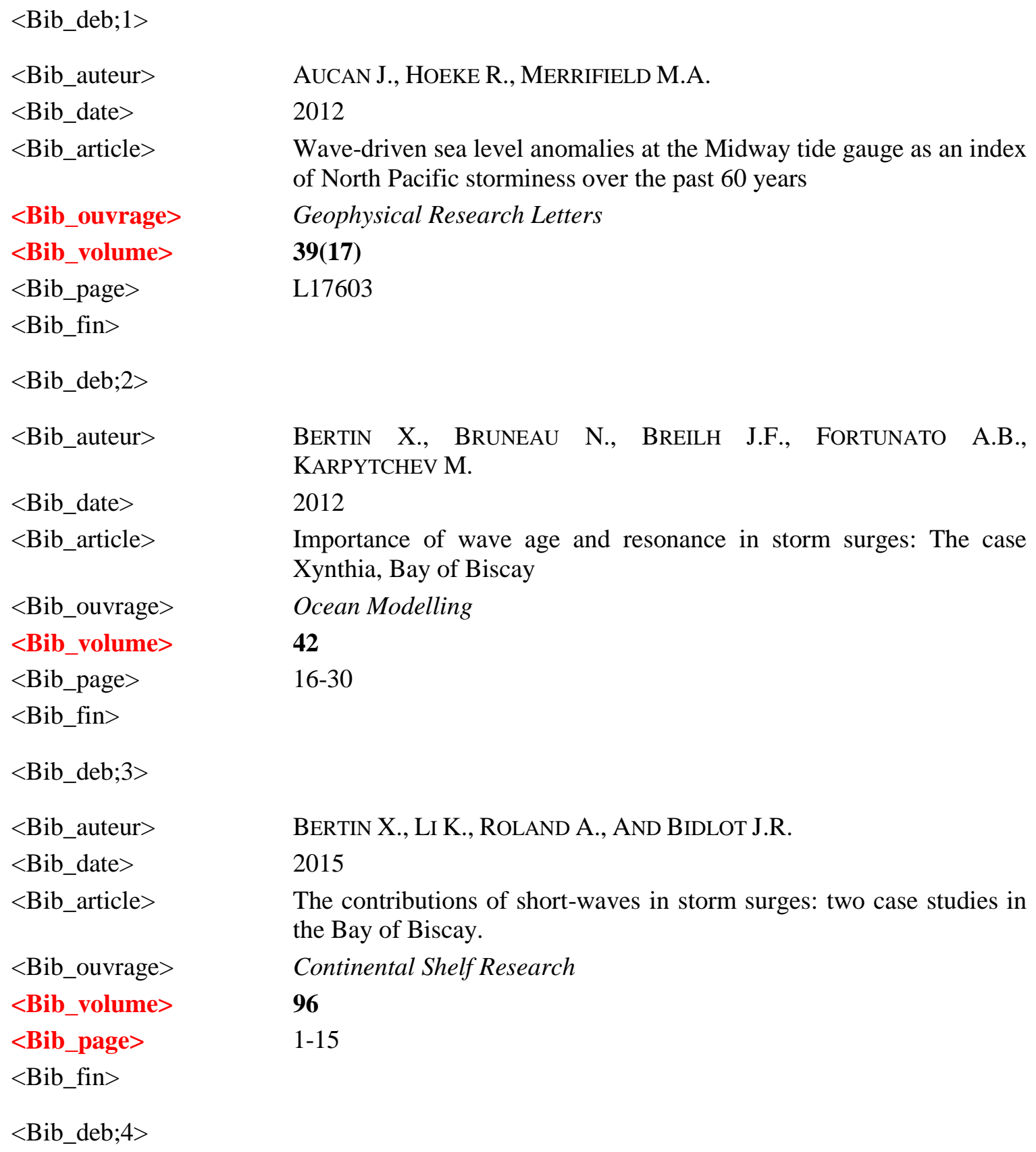




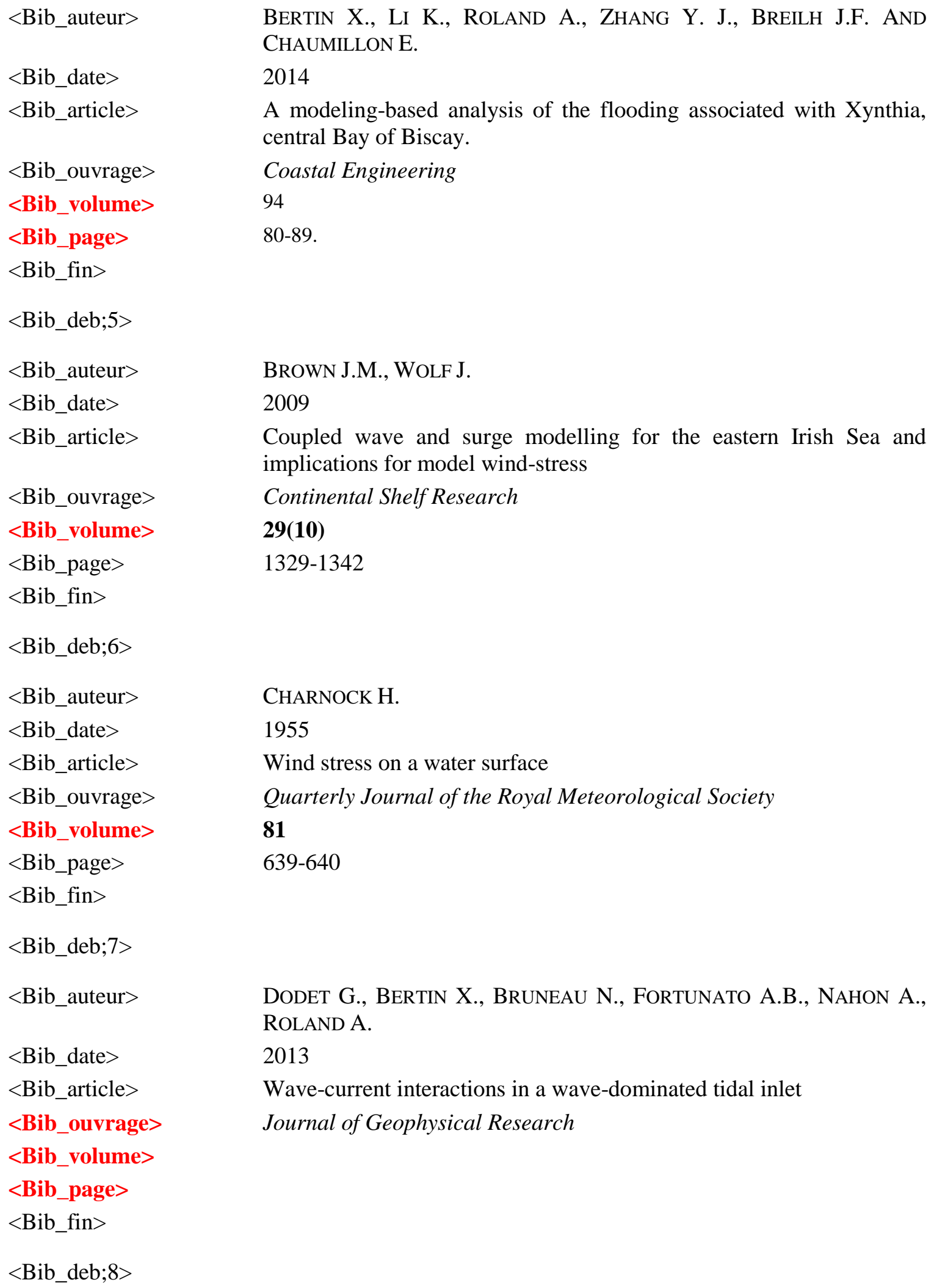
A modeling-based analysis of the flooding associated with Xynthia, central Bay of Biscay.

Coastal Engineering

94

80-89.

BROWN J.M., WOLF J.

2009

Coupled wave and surge modelling for the eastern Irish Sea and implications for model wind-stress

Continental Shelf Research

29(10)

$1329-1342$

\section{CHARNOCK H.}

1955

Wind stress on a water surface

Quarterly Journal of the Royal Meteorological Society

81

$639-640$

Dodet G., Bertin X., Bruneau N., Fortunato A.B., Nahon A., ROLAND A.

2013

Wave-current interactions in a wave-dominated tidal inlet

Journal of Geophysical Research 


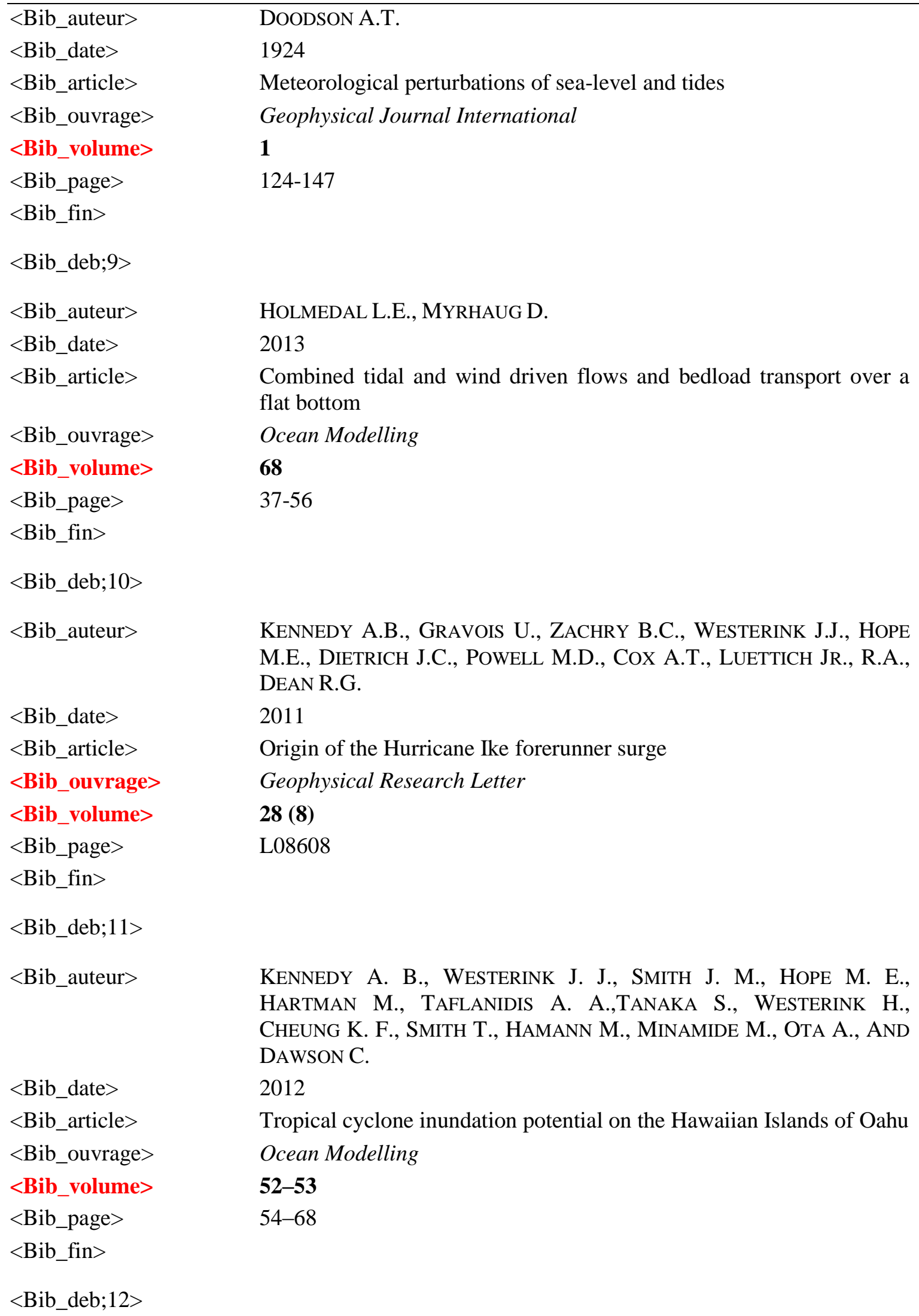

KenNedy A.B., Gravois U., ZaChry B.C., WesterinK J.J., HOPE M.E., Dietrich J.C., POWell M.D., CoX A.T., LueTtich JR., R.A., DEAN R.G.

2011

Origin of the Hurricane Ike forerunner surge

Geophysical Research Letter

28 (8)

L08608

Kennedy A. B., Westerink J. J., Smith J. M., Hope M. E., HARTMAN M., TAFlanidis A. A.,TANAKA S., WESTERINK H., Cheung K. F., Smith T., Hamann M., Minamide M., OtA A., AND DAWSON C.

2012

Tropical cyclone inundation potential on the Hawaiian Islands of Oahu Ocean Modelling

\section{2-53}

$54-68$ 


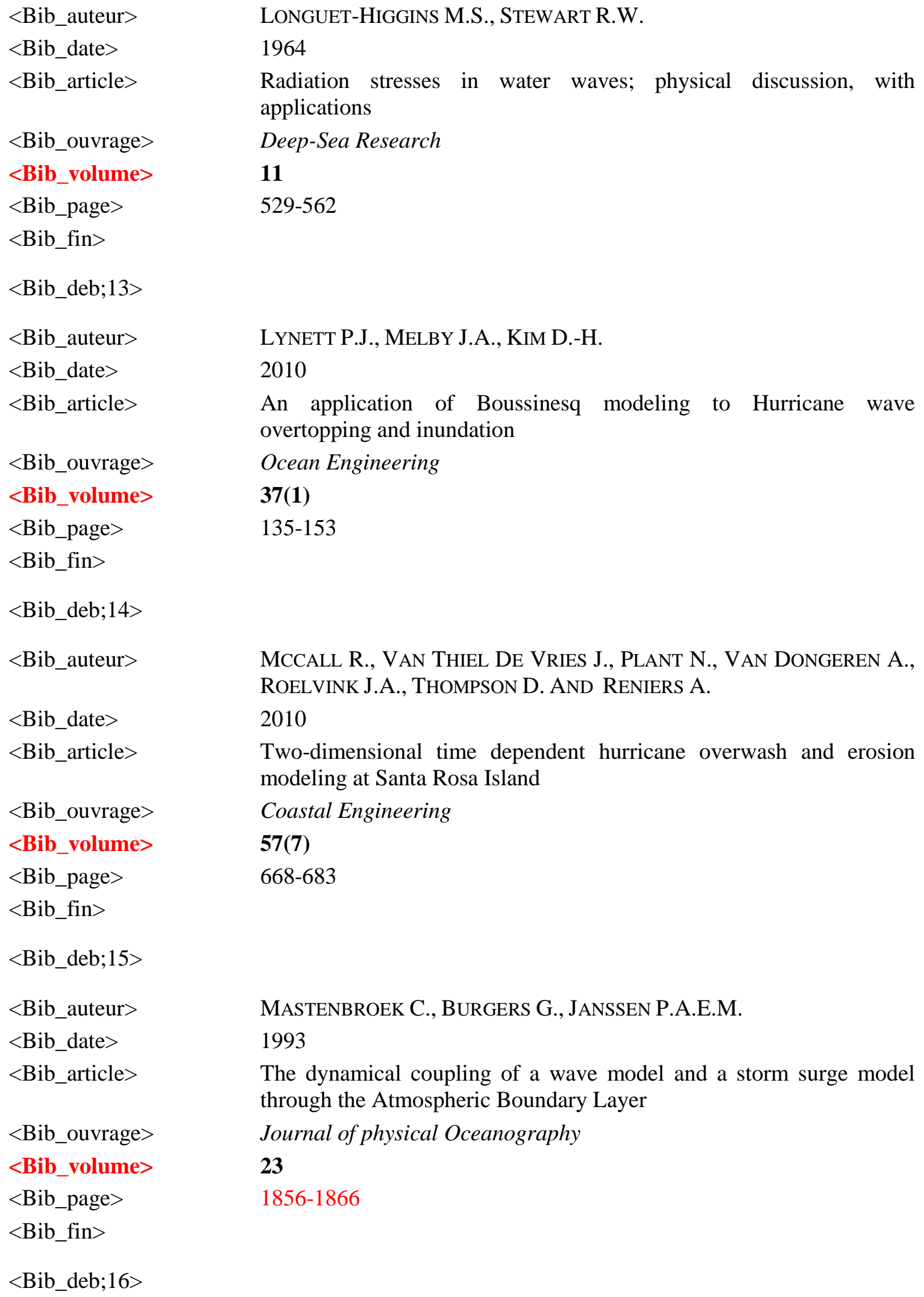




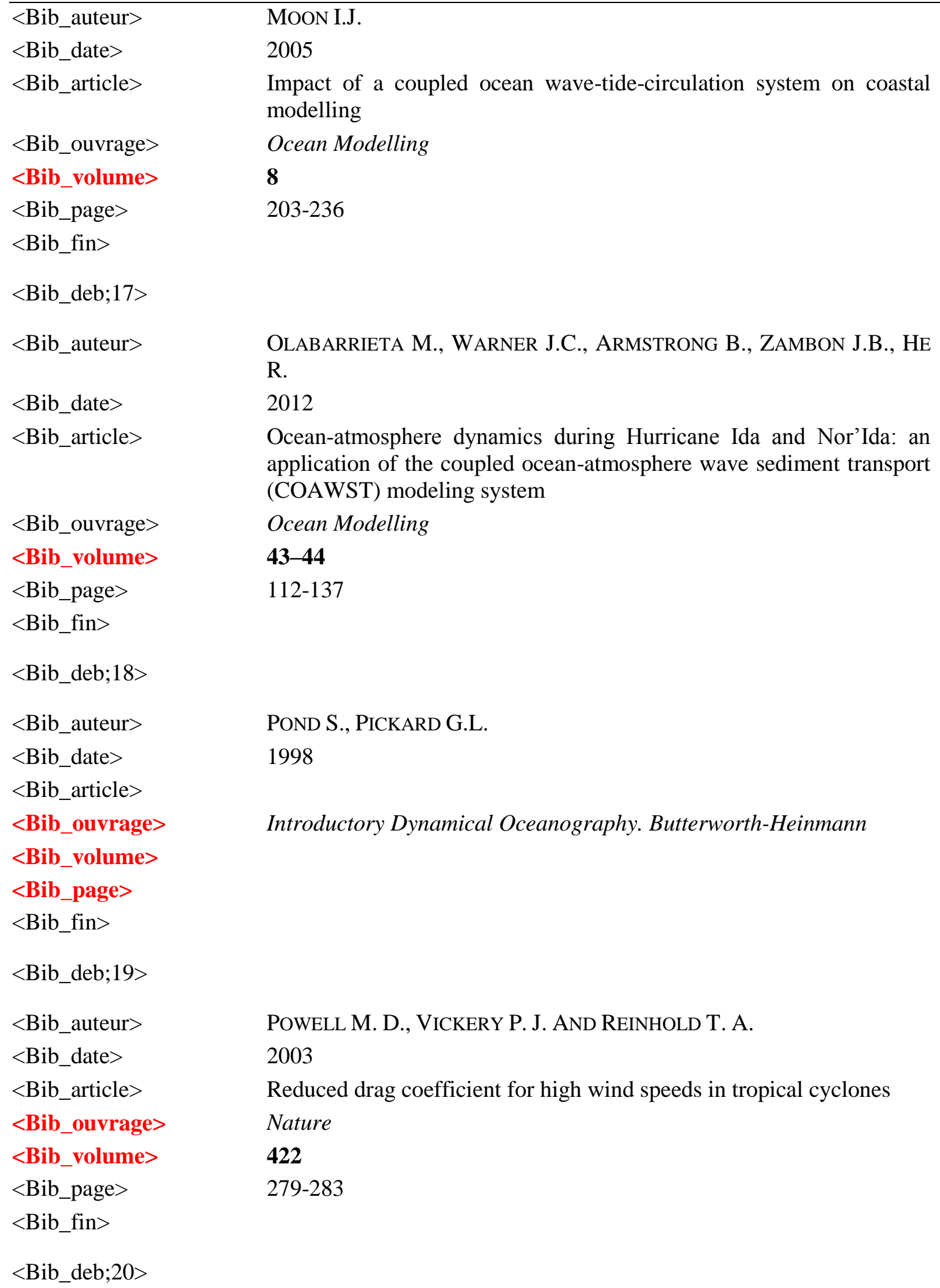
application of the coupled ocean-atmosphere wave sediment transport (COAWST) modeling system

Ocean Modelling

43-44

POND S., PICKARD G.L.

1998

Introductory Dynamical Oceanography. Butterworth-Heinmann

POWELl M. D., VICKERY P. J. AND REINHOLD T. A.

2003

Reduced drag coefficient for high wind speeds in tropical cyclones Nature

422

279-283 


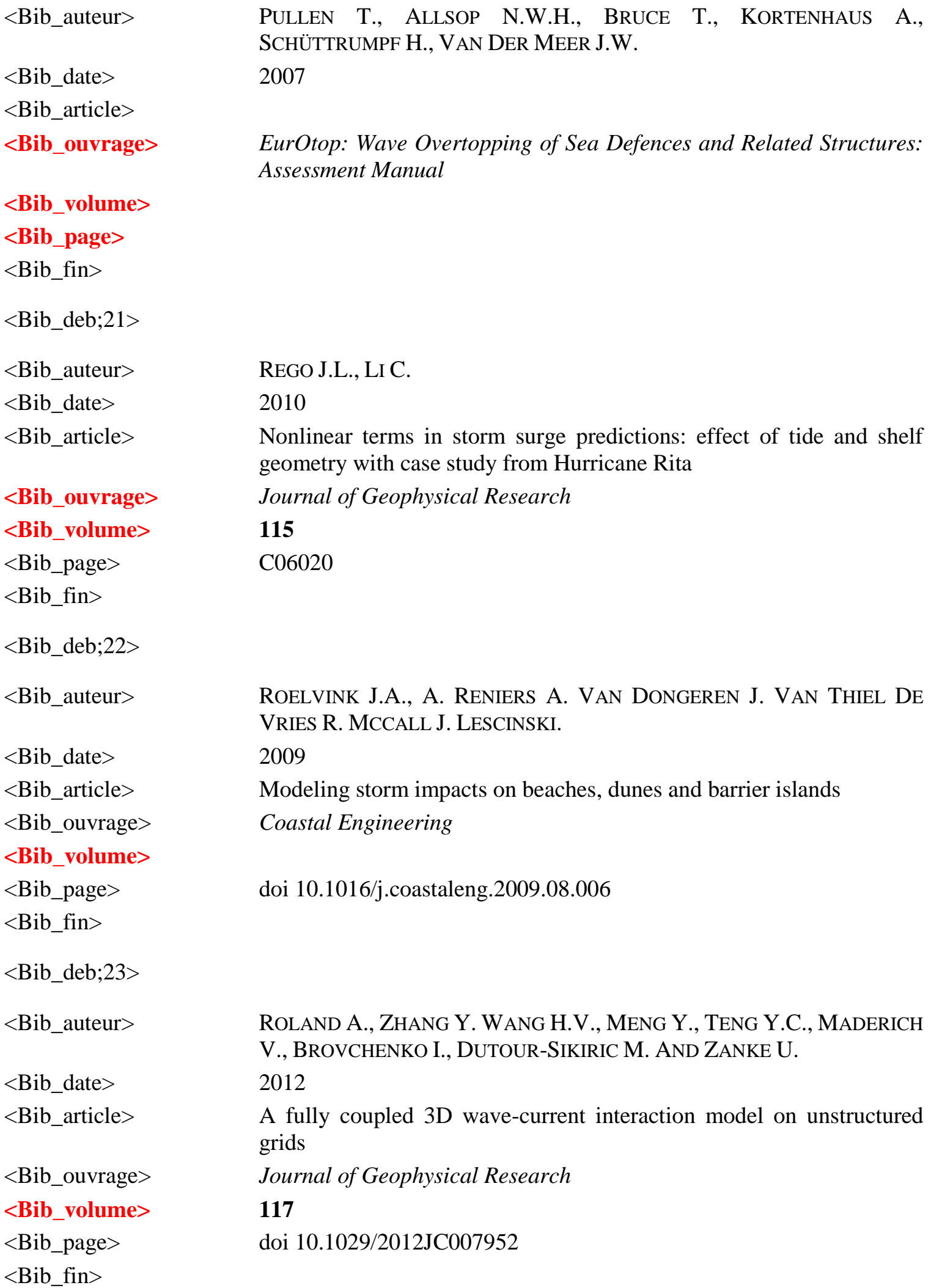

A fully coupled 3D wave-current interaction model on unstructured grids

Journal of Geophysical Research

117

doi 10.1029/2012JC007952

$<$ Bib_fin $>$

Saha, S., Moorthi, S., Pan, H.-L., Wu, X., Wang, J., Nadiga, S., Tripp, P., Kistler, R., Woollen, J., Behringer, D., Liu, H., Stokes, D., Grumbine, R., Gayno, G., Wang, J., Hou, Y.-T., Chuang, H.-Y., Juang, H.-M.H., Sela, J., Iredell, M., Treadon, R., Kleist, D., Van Delst, P., Keyser, D., Derber, J., Ek, M., Meng, J., Wei, H., Yang, R., Lord, S., Van Den Dool, H., Kumar, A., Wang, W., Long, C., Chelliah, M., Xue, Y., Huang, B., Schemm, J.-K., Ebisuzaki, W., Lin, R., Xie, P., Chen, M., Zhou, S., Higgins, W., Zou, C.-Z., Liu, Q., Chen, Y., Han, Y., Cucurull, L., Reynolds, R.W., Rutledge, G., Goldberg, M., 2010. The NCEP climate fore-cast system reanalysis. Bull. Am. Meteorol. Soc. 91, 1015-1057. 
<Bib_deb;24>

<Bib_auteur>

$<$ Bib_date>

<Bib_article>

<Bib_ouvrage>

<Bib_volume>

<Bib_page>

$<$ Bib_fin>

<Bib_deb;25>

<Bib_auteur>

<Bib_date>

<Bib_article>

<Bib_ouvrage>

<Bib_volume>

<Bib_page>

$<$ Bib_fin>

<Bib_deb;26>

<Bib_auteur>

$<$ Bib_date>

<Bib_article>

<Bib_ouvrage>

<Bib_volume>

<Bib_page>

$<$ Bib_fin>

<Bib_deb;27>

<Bib_auteur>

$<$ Bib_date>

<Bib_article>

<Bib_ouvrage>

<Bib_volume>

<Bib_page>

<Bib_fin>

<Bib_deb;28>
SteWARt R. W.

1974

The air-sea momentum exchange

Boundary Layer Meteorology

6

$151-167$

TAKagaki N., Komori S., SuZuKi N., Iwano K., KURAMOto T., SHIMADA S., KUROSE R., TAKAHASHI K.

2012

Strong correlation between the drag coefficient and the shape of the wind sea spectrum over a broad range of wind

Geophysical Research Letters

39

L23604

WOLF J., FLATHER R.A.

2005

Modelling waves and surges during the 1953 storm. Philosophical transactions of the royal society A: mathematical

Physical and Engineering Sciences

363

$1359-1375$

ZHANG Y. AND BAPTISTA A.M.

2008

SELFE: A semi-implicit Eulerian-Lagrangian finite-element model for cross-scale ocean circulation

Ocean Modelling

21(3-4)

$71-96$ 
$<$ Bib_auteur >

$<$ Bib_date>

$<$ Bib_article>

<Bib_ouvrage>

$\langle$ Bib_volume>

$<$ Bib_page>

$<$ Bib_fin>
ZiJlema M., Stelling G. AND SMit P.

2011

SWASH: An operational public domain code for simulating wave fields and rapidly varied flows in coastal waters

Coastal Engineering

58 (10)

992-1012 